\begin{tabular}{|l|l|l||}
\hline \multicolumn{2}{|c|}{ PublisherInfo } \\
\hline \hline PublisherName & $:$ & BioMed Central \\
\hline \hline PublisherLocation & $:$ & London \\
\hline \hline PublisherImprintName & $:$ & BioMed Central \\
\hline \hline
\end{tabular}

\title{
Stem-cell genomics
}

\begin{tabular}{|l|l|l||}
\hline \multicolumn{2}{|c|}{ ArticleInfo } \\
\hline \hline ArticleID & $:$ & 4139 \\
\hline \hline ArticleDOI & $:$ & $10.1186 /$ gb-spotlight-20010706-01 \\
\hline \hline ArticleCitationID & $:$ & spotlight-20010706-01 \\
\hline \hline ArticleSequenceNumber & $:$ & 210 \\
\hline \hline ArticleCategory & $:$ & Research news \\
\hline \hline ArticleFirstPage & $:$ & 1 \\
\hline \hline ArticleLastPage & $:$ & 2 \\
\hline \hline & & RegistrationDate : 2001-07-06 \\
ArticleHistory & $:$ & OnlineDate \\
\hline \hline ArticleCopyright & $:$ & BioMed Central Ltd2001 \\
\hline \hline ArticleGrants & $:$ & \\
\hline \hline ArticleContext & $:$ & 130592211 \\
\hline \hline
\end{tabular}




\section{Jonathan B Weitzman}

Email: jonathanweitzman@hotmail.com

The surprising plasticity and trans-differentiation of transplanted stem-cells suggest that there may be a set of universal stem-cell genes that govern the undifferentiated proliferative state. In the July 3 Proceedings of the National Academy of Sciences, Terskikh et al. report attempts to define a common stem-cell gene profile by comparing hematopoietic and neural stem-cells (Proc Natl Acad Sci USA 2001, 98:7934-7939). They isolated hematopoietic stem cells (HSC) from mouse bone marrow and created a subtracted cDNA library enriched in HSC genes. High-throughput sequencing identified 223 sequences representing known (40\%) and novel genes. There were similarities and differences between these adult HSC genes and those characterized in fetal HSC. The HSC enrichment was demonstrated by PCR, northern and in situ hybridization experiments. The genes encode cell-surface proteins (notably two novel seven-transmembrane receptors), nuclear proteins and signalling molecules. Terskikh et al. compared their results with analysis of neural stem cellsand performed microarray analysis to define common stem-cell genes. Some of the HSC-enriched genes were expressed in the germinal zones of the brain, which contain neural progenitor cells. The authors suggest that identifying overlapping stem-cell gene profiles may indicate genes that regulate the common feature of stem cells, namely their capacity for self-renewal.

\section{References}

1. Translating stem and progenitor cell biology to the clinic: barriers and opportunities

2. Proceedings of the National Academy of Sciences, [http://www.pnas.org]

3. The stem-cell database, [http://stemcell.princeton.edu]

4. A genetic analysis of neural progenitor differentiation

This PDF file was created after publication. 